\title{
ANALISIS KINERJA BELANJA DALAM LAPORAN REALISASI ANGGARAN (LRA) PADA DINAS SOSIAL KABUPATEN BERAU
}

\section{Penulis}

\section{${ }^{1}$ Warti Ratnasari}

${ }^{2}$ Siti Munawaroh

Sekolah Tinggi Ilmu Ekonomi

Muhammadiyah Tanjung Redeb

Email: Siti010890@gmail.com

\section{Info Artikel}

p-ISSN : 2615-1871

e-ISSN : 2615-5850

Volume 2 Nomor 1, Maret 2019

\section{Received 6th January 2019 / Accepted 14th February 2019}

\section{ABSTRAK}

Laporan Realisasi Anggaran (LRA) yang dipublikasikan pemerintah daerah memberikan informasi yang sangat bermanfaat untuk menilai kinerja keuangan daerah. LRA menjadi salah satu laporan pertanggung- jawaban keuangan daerah yang dinilai paling utama. Berdasarkan LRA tersebut pembaca laporan dapat membuat analisis kinerja laporan keuangan berupa analisis pendapatan, analisis belanja dan analisis pembiayaan. Tujuan dari penelitian ini adalah untuk mengetahui dan menganalisis kinerja belanja dalam Laporan Realisasi Anggaran (LRA) Dinas Sosial Kabupaten Berau. Metode analisis yang digunakan dalam penelitian ini yaitu metode deskriptif kuantitatif. Alat analisis yang digunakan yaitu: Analisis Varians Belanja (Selisih Belanja), Analisis Pertumbuhan Belanja, Analisis Keserasian Belanja dan Analisis Efisiensi Belanja. Berdasarkan hasil analisis yang telah dilakukan dapat disimpulkan bahwa menolak hipotesis yang telah diajukan sebelumnya, karena kinerja belanja dalam Laporan Realisasi Anggaran (LRA) pada Dinas Sosial Kabupaten Berau menurun pada Tahun 2017, dibuktikan dari: 1). Tahun 2017 jumlah anggaran belanja (Rp10.830.810.200) dan realisasi belanja (Rp 9.770.219.869) menurun pada Tahun 2016 dengan anggaran belanja Rp14.879.889.739 dan realisasinya $R p 12.558 .626 .940$. 2). Varians belanja pada Tahun 2017 (9,79\%) lebih rendah dari Tahun 2016 (15,60\%). 3). Rasio pertumbuhan belanja pada Tahun 2017 turun sebesar 22,20\%.

Kata Kunci: Kinerja Belanja, Varians Belanja (Selisih Belanja), Pertumbuhan Belanja, Keserasian Belanja, Efisiensi Belanja.

\section{PENDAHULUAN}

Laporan keuangan disusun untuk menyediakan informasi yang relevan mengenai posisi keuangan dan seluruh transaksi yang dilakukan oleh suatu entitas pelaporan dalam suatu periode pelaporan. Laporan keuangan terutama digunakan untuk membandingkan realisasi pendapatan, belanja, transfer dan pembiayaan dengan anggaran yang telah ditetapkan, menilai dan meng-evaluasi kondisi keuangan, efektifitas dan efisiensi suatu entitas pelaporan dan membantu menentukan ketentuan 
terhadap peraturan perundang-undangan. Seiring dengan reformasi dibidang keuangan negara maka perlu dilakukan perubahan-perubahan diber-bagai bidang untuk mendukung agar reformasi dibidang keuangan negara dapat berjalan dengan baik.

Salah satu perubahan yang signifikan adalah perubahan dibidang akuntansi pemerintahan karena melalui proses akuntansi akan dihasilkan informasi keuangan yang tersedia bagi berbagai pihak untuk digunakan sesuai dengan tujuan masing-masing. Penyusunan laporan keuangan yang berpedoman pada standar akuntansi pemerintahan sesungguhnya adalah dalam rangka meningkatkan kuantitas laporan keuangan, sehingga laporan keuangan yang dimaksud dapat meningkatkan kredibilitasnya dan pada gilirannya nanti akan dapat mewujudkan transparansi dan akuntabilitas penge-lolaan keuangan pemerintah daerah sehingga good governance dapat tercapai.

Upaya kongkrit dalam mewujudkan akuntabilitas dan transparansi dilingkungan pemerintah mengharuskan setiap pengelolaan keuangan negara menyampaikan laporan pertanggung-jawaban pengelolaan keuangan negara dengan cakupan yang lebih luas dan tepat waktu. Undang-undang Nomor 17 Tahun 2003 tentang Keuangan Negara menegaskan tentang pelaksanaan APBD, dimana kepala daerah wajib menyampaikan rancangan peraturan daerah tentang pertanggunjawaban pelaksanaan APBD kepada DPRD berupa laporan keuangan berdasarkan PP No. 71 Tahun 2010 yang terdiri dari Laporan Realisasi Anggaran, Neraca, Laporan Arus Kas, Laporan Operasional, Laporan Perubahan Ekuitas, Laporan Perubahan Saldo Anggaran Lebih dan Catatan atas Laporan Keuangan.

Laporan Realisasi Anggaran (LRA) yang dipublikasikan pemerintah daerah memberikan informasi yang sangat bermanfaat untuk menilai kinerja keuangan daerah. Jika dibandingkan dengan neraca, LRA menduduki prioritas yang lebih penting. LRA ini merupakan jenis laporan keuangan daerah yang paling dahulu dihasilkan sebelum membuat lapora neraca, laporan operasional serta laporan arus kas.

Anggaran dalam pemerintahan merupakan tulang punggung penye-lenggaraan pemerintahan dan pem-bangunan daerah. Anggaran memiliki peran penting sebagai alat stabilisasi, distribusi, alokasi sumber daya publik, perencanaan dan pengendalian organi-sasi serta penilaian kinerja. Oleh karena itu, LRA menjadi salah satu laporan pertanggung- jawaban keuangan daerah yang dinilai paling utama. Berdasarkan LRA tersebut pembaca laporan dapat membuat analisis kinerja laporan keuangan berupa analisis pendapatan, analisis belanja dan analisis pembiayaan.

Dinas Sosial Kabupaten Berau wajib menyampaikan laporan pertanggungjawaban keuangan untuk dinilai apakah anggaran pada Dinas Sosial Kabupaten Berau sudah direalisasikan dengan baik atau tidak. Sejauh mana Dinas Sosial Kabupaten Berau melaku-kan efisiensi anggaran, menghindari pengeluaran yang tidak perlu dan tidak tepat sasaran.

Pertanggungjawaban untuk setiap kegiatan tidak cukup dengan laporan lisan saja, namun juga perlu didukung dengan laporan keuangan secara tertulis. Dalam hal ini laporan pertanggung-jawaban tersebut oleh Dinas Sosial Kabupaten Berau dituangkan dalam LRA yang rutin dilaksanakan setiap tahunnya. Dengan adanya LRA yang merupakan pertanggungjawaban tertulis atas kinerja keuangan yang telah dicapai, maka laporan tersebut harus disajikan secara tepat waktu dan dapat diandalkan, selain itu juga perlu dilengkapi dengan pengungkapan yang memadai mengenai informasi-informasi yang dapat mem-pengaruhi kebijakan yang diambil.

Belanja dalam LRA Dinas Sosial Kabupaten Berau merupakan komponen penting yang mendapat menggambarkan bagaimana kinerja keuangan yang telah dilaksanakan. 
Belanja daerah tersebut juga mencerminkan kebijakan dalam menghasilkan pendapatan yang merupa-kan suatu hal yang lebih sulit dibanding-kan membelanjakannya. Karena sifat belanja yang relatif mudah dilakukan dan rentan akan terjadinya inefisiensi dan kebocoran, maka tindakan perencanaan, pengendalian dan peng-awasan terhadap belanja daerah sangat penting dilakukan. Setelah dibelanjakan dan dilaporkan dalam LRA, analisis terhadap belanja ini pun mutlak harus dilakukan untuk dijadikan dasar evaluasi, koreksi dan perbaikan di masa mendatang. Berdasarkan uraian tersebut di atas maka penulis tertarik untuk melakukan penelitian guna menganalisis kinerja belanja dalam Laporan Realisasi Anggaran (LRA) pada Dinas Sosial Kabupaten Berau.

\section{TINJAUAN PUSTAKA}

\section{Akuntansi Pemerintahan}

American institute of certified publik accounting (AICPA) dalam Harahap (2013:4) mendefinisikan akuntansi dengan pengertian akuntansi adalah seni pencatatan, penggolongan dan pengiktisaran dengan cara tertentu dan dalam ukuran moneter, transaksi dan kejadian-kejadian yang umumnya bersifat keuangan dan termasuk menafsirkan hasil-hasilnya. Halim dan kusufi (2013:6) memberikan definisi akuntansi adalah suatu aktifitas jasa. Fungsinya adalah penyediaan informasi kuantitatif, terutama yang bersifat keuangan, tentang satuan-satuan ekonomi yang dapat bermanfaat dalam pengambilan keputusan ekonomis dalam menetapkan pilihan-pilihan yang logis diantara berbagai tindakan alternatif.

Menurut Langenderfer dalam Mardiasmo (2009:160) mendefinisikan akuntansi merupakan suatu sistem pengukuran dan sistem komunikasi untuk memberikan informasi ekonomi dan sosial atas suatu entitas yang dapat didefinisikan sehingga memungkinkan pemakai untuk membuat pertimbangan dan keputusan mengenai alokasi sumber daya yang optimal dan tingkat pencapaian tujuan organisasi.

Berdasarkan pengertian di atas, maka dapat disimpulkan bahwa informasi akuntansi diharapkan dapat digunakan sebagai dasar pengambilan keputusan ekonomi dengan cara mencatat, menggolongkan dan mengikhtisarkan transaksi-transaksi yang bersifat keuangan dalam bentuk laporan keuangan dan melaporkan transaksi-transaksi ekonomi tersebut kepada pihak-pihak yang berkepentingan.

\section{Akuntansi Belanja}

Halim dan Kusufi (2013:102) memberikan definisi belanja menurut basis kas adalah semua pengeluaran oleh bendahara umum negara/daerah yang mengurangi ekuitas dana jangka pendek dalam periode tahun anggaran bersangkutan yang tidak akan diperoleh pembayarannya kembali oleh pemerintah. Sedangkan menurut basis akrual, belanja merupakan kewajiban pemerintah yang diakui sebagai pengurang nilai kekayaan bersih.

\section{Belanja Daerah}

Belanja daerah merupakan semua kewajiban daerah yang diakui sebagai pengeluaran nilai kekayaan bersih dari periode tahun anggaran yang bersangkutan. Berdasarkan Kepmendagri Nomor 29 Tahun 2002, belanja terdiri dari: (a) belanja aparatur daerah; (b) belanja pelayanan publik; (c) belanja bagi hasil dan bantuan keuangan; dan (d) belanja tidak tersangka.

Masing-masing belanja yang meliputi belanja administrasi umum, belanja operasi dan pemeliharaan serta belanja modal. Belanja tidak tersangka dianggarkan untuk 
pengeluaran lainnya yang sangat diperlukan dalam rangka penyelenggaraan kewenangan pemerintah daerah, yaitu:

1. Pengeluaran-pengeluaran yang sangat dibutuhkan untuk penyediaan sarana dan prasarana langsung dengan pelayanan masyarakat, yang anggarannya tidak tersedia dalam tahun anggaran yang bersangkutan.

2. Pengembalian atas kelebihan penerimaan yang terjadi dalam tahun anggaran yang telah ditutup dengan didukung bukti-bukti yang sah.

\section{METODE PENELITIAN}

\section{a. Unit Analisis, Populasi dan Sampel}

Unit analisis dalam penelitian ini adalah Dinas Sosial Kabupaten Berau, yang beralamat di Jalan Pemuda No.29 Kelurahan Tanjung Redeb Kecamatan Tanjung Redeb Kabupaten Berau. Populasi dalam penelitian ini adalah seluruh Laporan Realisasi Anggaran (LRA) pada Dinas Sosial Kabupaten Berau sejak berdirinya hingga periode anggaran Tahun 2017. Sampel yang digunakan dalam penelitian ini adalah Laporan Realisasi Anggaran (LRA) pada Dinas Sosial Kabupaten Berau periode anggaran Tahun 2016-2017. Metode pengambilan sampel yang digunakan adalah Nonprobability Sampling dengan teknik Purposive Sampling.

\section{b. Alat Analisis}

Alat analisis yang digunakan untuk mengetahui kinerja belanja Dinas Sosial Kabupaten Berau adalah:

1. Analisis Varians Belanja (Selisih Belanja)

Analisis varians merupakan analisis terhadap perbedaan atau selisih antara realisasi belanja dengan anggaran belanja, dengan menggunakan rumus dari Mahmudi (2010:157):

$$
\text { Varians Belanja }=\text { Realisasi Belanja }- \text { Anggaran Belanja }
$$

2. Analisis Pertumbuhan Belanja

Analisis pertumbuhan belanja bermanfaat untuk mengetahui perkembangan belanja dari tahun ke tahun, dengan menggunakan rumus dari Mahmudi (2010:160):

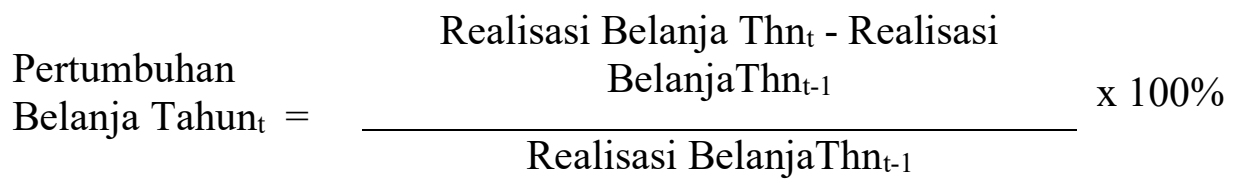

3. Analisis Keserasian Belanja

Analisis keserasian belanja bermanfaat untuk mengetahui keseimbangan antar belanja. Hal ini terkait dengan fungsi anggaran sebagai alat distribusi, alokasi dan stabilisasi (Mahmudi, 2010:162).

a. Analisis Belanja Operasi terhadap Total Belanja

Analisis belanja operasi terhadap total belanja merupakan perbandingan antara total realisasi belanja operasi dengan total belanja. Rasio ini memberikan informasi mengenai porsi belanja yang dialokasikan untuk belanja operasi pada tahun anggaran bersangkutan, menggunakan rumus dari Mahmudi (2010:164):

Rasio Belanja Operasi $\quad$ Total Belanja Operasi $\quad$ x $100 \%$


terhadap Belanja $=$

Total Belanja

b. Analisis Belanja Modal terhadap Total Belanja

Analisis belanja modal terhadap total belanja merupakan perbandingan antara total realisasi belanja modal dengan total belanja. Rasio ini memberikan informasi mengenai porsi belanja yang dialokasikan untuk belanja modal pada tahun anggaran bersangkutan, menggunakan rumus dari Mahmudi (2010:164):

Rasio Belanja Modal terhadap Belanja $=$ Total Belanja Modal Total Belanja x $100 \%$

c. Analisis Belanja Tak Terduga terhadap Total Belanja

Analisis belanja tak terduga terhadap total belanja merupakan perbandingan antara total realisasi belanja tak terduga dengan total belanja. Rasio ini memberikan informasi mengenai porsi belanja yang dialokasikan untuk belanja tak terduga pada tahun anggaran bersangkutan, dengan menggunakan rumus dari Mahmudi (2010:164):

$\begin{array}{ll}\text { Rasio Belanja Tak Terduga } & \text { Total Belanja Tak Terduga } \\ \text { terhadap Belanja }= & \text { Total Belanja }\end{array} 100 \%$

4. Analisis Efisiensi Belanja

Analisis efisiensi belanja merupakan perbandingan antara realisasi belanja dengan anggaran belanja. Rasio efisiensi belanja ini digunakan untuk mengukur tingkat penghematan anggaran yang dilakukan Dinas Sosial Kabupaten Berau, dengan rumus menggunakan dari Mahmudi (2010:166):

Rasio Efisiensi Belanja $=\frac{\text { Realisasi Belanja }}{\text { Anggaran Belanja }} \times 100 \%$

\section{HASIL PENELITIAN}

Rincian anggaran dan realisasi keuangan baik dari dana rutin maupun dana pembangunan Dinas Sosial Kabupaten Berau Tahun Anggaran 2016 dan 2017, sebagai berikut:

Tabel 1. Laporan Realisasi Anggaran Pendapatan dan Belanja Daerah Dinas Sosial Tahun Anggaran 2016 (dalam rupiah).

\begin{tabular}{|c|c|c|c|}
\hline URAIAN & ANGGARAN & REALISASI & SISA DANA \\
\hline \multicolumn{4}{|l|}{ Belanja Operasi } \\
\hline Belanja Pegawai & 5.582 .119 .908 & 4.711 .309 .202 & 870.810 .706 \\
\hline \multirow[t]{2}{*}{ Belanja Barang } & 8.806 .459 .405 & 7.432 .651 .738 & 1.373 .807 .667 \\
\hline & 14.388 .579 .313 & 12.143 .960 .940 & 2.244 .618 .373 \\
\hline \multicolumn{4}{|l|}{ Belanja Modal } \\
\hline $\begin{array}{l}\text { Belanja Peralatan dan } \\
\text { Mesin }\end{array}$ & 260.709 .716 & 220.039 .000 & 40.670 .716 \\
\hline \multirow[t]{2}{*}{$\begin{array}{l}\text { Belanja Bangunan dan } \\
\text { Gedung }\end{array}$} & 230.600 .711 & 194.627 .000 & 35.973 .711 \\
\hline & 491.310.427 & 414.666 .000 & 76.644 .427 \\
\hline Jumlah & 14.879 .889 .739 & 12.558 .626 .940 & 2.321.262.799 \\
\hline
\end{tabular}

Sumber: Dinas Sosial Kabupaten Berau, 2018.

Pada Tabel 1 di atas, selama Tahun 2016 anggaran yang tersedia sejumlah Rp14.879.889.739 dengan realisasi anggaran sejumlah Rp12.558.626.940 atau 84,40\% sehingga terdapat sisa dana sejumlah Rp2.321.262.799 atau 15,60\% pada akhir Tahun Anggaran 2016. 
Tabel 2. Laporan Realisasi Anggaran Pendapatan dan Belanja Daerah Dinas Sosial Tahun Anggaran 2017 (dalam rupiah)

\begin{tabular}{|c|c|c|c|}
\hline URALAN & ANGGARAN & REALISASI & SISA DANA \\
\hline \multicolumn{4}{|l|}{ Belanja Operasi } \\
\hline Belanja Pegawai & 4.721 .117 .000 & 4.362 .997 .796 & 358.119 .204 \\
\hline \multirow[t]{2}{*}{ Belanja Barang } & 5.611 .467 .200 & 4.924 .417 .073 & 687.050 .127 \\
\hline & 10.332.584.200 & 9.287.414.869 & 1.045 .169 .331 \\
\hline \multicolumn{4}{|l|}{ Belanja Modal } \\
\hline $\begin{array}{l}\text { Belanja Peralatan dan } \\
\text { Mesin }\end{array}$ & 332.834 .000 & 317.760 .000 & 15.074 .000 \\
\hline \multirow[t]{2}{*}{$\begin{array}{l}\text { Belanja Bangunan dan } \\
\text { Gedung }\end{array}$} & 165.392 .000 & 165.045 .000 & 347.000 \\
\hline & 498.226 .000 & 482.805 .000 & 15.421 .000 \\
\hline Jumlah & 10.830 .810 .200 & 9.770 .219 .869 & 1.060 .590 .331 \\
\hline
\end{tabular}

Pada Tabel 2 di atas, dapat diketahui bahwa selama Tahun 2017 anggaran yang tersedia Rp10.830.810.200 dengan realisasi anggaran hanya sejumlah Rp9.770.219.869 atau 90,21\% sehingga terdapat sisa dana Rp1.060.590.331 atau 9,79\% pada akhir Tahun Anggaran 2017. Tahun 2017 realisasi penyerapan anggaran sebesar 90,21\%, Tahun 2016 sebesar 84,40\%, Tahun 2015 sebesar 64,83\% serta pada Tahun 2014 sebesar 64,06\%. Dengan demikian realisasi penyerapan anggaran dari Tahun 2014 sampai dengan Tahun 2017 terus mengalami peningkatan.

\section{ANALISIS DAN PEMBAHASAN}

a. Analisis

Tabel 3. Analisis Varians Belanja Tahun Anggaran 2016-2017

\begin{tabular}{|c|c|c|c|c|}
\hline TAHUN & $\begin{array}{c}\text { REALISASI } \\
\text { (Rp) }\end{array}$ & $\begin{array}{c}\text { ANGGARAN } \\
\text { (Rp) }\end{array}$ & $\begin{array}{c}\text { SELISIH } \\
\text { (Rp) }\end{array}$ & $\%$ \\
\hline 2016 & 12.558 .626 .940 & $\mathbf{1 4 . 8 7 9 . 8 8 9 . 7 3 9}$ & -2.321 .262 .799 & $-15,60$ \\
\hline 2017 & 9.770 .219 .869 & 10.830 .810 .200 & -1.060 .590 .331 & -9.79 \\
\hline
\end{tabular}

Sumber: Data diolah, 2018.

Berdasarkan Tabel 3, terlihat bahwa selisih anggaran dan realisasi terbesar pada Tahun 2016 sejumlah Rp2.321.262.799 atau sebesar 15,60\%. Terjadi penurunan varians belanja pada Tahun 2017 jika dibandingkan dengan Tahun 2016, yaitu sebesar $5,81 \%$.

Tabel 4. Rasio Pertumbuhan Belanja Tahun Anggaran 2016-2017

\begin{tabular}{|l|r|r|r|r|}
\hline \multirow{2}{*}{ URAIAN } & \multicolumn{2}{|c|}{ REALISASI BELANJA (RP) } & \multicolumn{2}{c|}{ PERTUMBUHAN } \\
\cline { 2 - 5 } & \multicolumn{1}{c|}{$\mathbf{2 0 1 7}$} & \multicolumn{1}{c|}{$\mathbf{2 0 1 6}$} & $\begin{array}{c}\text { KENAIKAN } \\
\text { (PENURUNAN) }\end{array}$ & \multicolumn{1}{c|}{$\%$} \\
\hline Belanja & $\mathbf{9 . 7 7 0 . 2 1 9 . 8 6 9}$ & $\mathbf{1 2 . 5 5 8 . 6 2 6 . 9 4 0}$ & $\mathbf{( 2 . 7 8 8 . 4 0 7 . 0 7 1 )}$ & $\mathbf{- 2 2 , 2 0}$ \\
\hline Belanja Operasi & $\mathbf{9 . 2 8 7 . 4 1 4 . 8 6 9}$ & $\mathbf{1 2 . 1 4 3 . 9 6 0 . 9 4 0}$ & $\mathbf{( 2 . 8 5 6 . 5 4 6 . 0 7 1 )}$ & $\mathbf{- 2 3 , 5 2}$ \\
\hline Belanja Pegawwai & 4.362 .997 .796 & 4.711 .309 .202 & $(348.311 .406)$ & $-7,39$ \\
\hline Belanja Barang & 4.924 .417 .073 & 7.432 .651 .738 & $(2.508 .234 .665)$ & $-33,75$ \\
\hline Belanja Modal & $\mathbf{4 8 2 . 8 0 5 . 0 0 0}$ & $\mathbf{4 1 4 . 6 6 6 . 0 0 0}$ & $\mathbf{6 8 . 1 3 9 . 0 0 0}$ & $\mathbf{1 6 , 4 3}$ \\
\hline $\begin{array}{l}\text { Belanja Peralatan dan } \\
\text { Mesin }\end{array}$ & 317.760 .000 & 220.039 .000 & 97.721 .000 & 44,41 \\
\hline $\begin{array}{l}\text { Belanja Bangunan dan } \\
\text { Gedung }\end{array}$ & $\mathbf{1 6 5 . 0 4 5 . 0 0 0}$ & 194.627 .000 & $(29.582 .000)$ & $-\mathbf{1 5 , 2 0}$ \\
\hline
\end{tabular}

Sumber: Data diolah 2018 . 
Pada Tabel 4 dapat dilihat bahwa rasio pertumbuhan belanja pada Tahun 2017, dimana secara keseluruhan menunjukkan penurunan pertumbuhan terkecuali pada belanja peralatan dan mesin sebesar 97.721 .000 atau 44,41\%. Penurunan tertinggi pada belanja barang sebesar Rp2.508.234.665 atau 33,75\%. Secara umum total belanja turun sebesar Rp2.788.407.071 atau 22,20\%.

Tabel 5. Analisis Belanja Operasi Terhadap Total Belanja

\begin{tabular}{|c|r|r|c|}
\hline TAHUN & $\begin{array}{c}\text { TOTAL BELANJA } \\
\text { OPERASI (Rp) }\end{array}$ & $\begin{array}{c}\text { TOTAL } \\
\text { BELANJA (Rp) }\end{array}$ & RASIO (\%) \\
\hline 2016 & 12.143 .960 .940 & $\mathbf{1 2 . 5 5 8 . 6 2 6 . 9 4 0}$ & 96,70 \\
\hline 2017 & 9.287 .414 .869 & 9.770 .219 .869 & 95,06 \\
\hline
\end{tabular}

Sumber: Data diolah, 2018.

Dari Tabel 5 terlihat adanya penurunan rasio pada Tahun 2017. Rasio tertinggi terdapat pada Tahun 2016 sebesar 96,70\% dan rasio terendah pada Tahun 2017 sebesar $95,06 \%$.

Tabel 6. Analisis Belanja Modal Terhadap Total Belanja

\begin{tabular}{|c|c|c|c|}
\hline TAHUN & $\begin{array}{c}\text { TOTAL BELANJA } \\
\text { MODAL (Rp) }\end{array}$ & $\begin{array}{c}\text { TOTAL } \\
\text { BELANJA (Rp) }\end{array}$ & RASIO (\%) \\
\hline 2016 & $\mathbf{4 1 4 . 6 6 6 . 0 0 0}$ & $\mathbf{1 2 . 5 5 8 . 6 2 6 . 9 4 0}$ & 3.30 \\
\hline 2017 & 482.805 .000 & 9.770 .219 .869 & 4.94 \\
\hline
\end{tabular}

Berdasarkan Tabel 6 di atas dapat dilihat rasio pada Tahun 2016 dan 2017. Rasio tertinggi pada Tahun 2017 sebesar 4,94\% dan rasio terendah pada Tahun 2016 sebesar $3,30 \%$.

Tabel 7. Rasio Efisiensi Belanja Tahun Anggaran 2016-2017

\begin{tabular}{|c|c|c|c|}
\hline TAHUN & $\begin{array}{c}\text { REALISASI } \\
\text { (Rp) }\end{array}$ & $\begin{array}{c}\text { ANGGARAN } \\
\text { (Rp) }\end{array}$ & $\begin{array}{c}\text { PERSENTASE } \\
\text { (\%) }\end{array}$ \\
\hline 2016 & 12.558 .626 .940 & $\mathbf{1 4 . 8 7 9 . 8 8 9 . 7 3 9}$ & 84,40 \\
\hline 2017 & 9.770 .219 .869 & $\mathbf{1 0 . 8 3 0 . 8 1 0 . 2 0 0}$ & 90,21 \\
\hline \multicolumn{3}{|r|}{ Rata-rata } & 87,30 \\
\hline
\end{tabular}

Sumber: Data diolah, 2018.

Berdasarkan pada Tabel 7 di atas dapat dilihat rasio efisiensi belanja mengalami peningkatan pada Tahun 2017. Rasio efisiensi belanja pada Tahun 2016 yaitu 84,40\%, sedangkan rasio efisiensi pada Tahun 2017 meningkat menjadi 90,21\%. Rata-rata rasio efisiensi belanja sebesar $87,30 \%$.

\section{b. Pembahasan}

\section{Analisis Varians Belanja (Selisih Belanja)}

Pada Tahun Anggaran 2016 terdapat selisih anggaran belanja dan realisasinya yang bersaldo negatif, ini menunjukkan adanya efesiensi/penghematan anggaran belanja sebesar Rp2.321.262.799 atau 15,60\%. Pada Tahun Anggaran 2017 selisih anggaran belanja sebesar 9,79\% atau Rp1.060.590.331.

Hal ini berarti bahwa Dinas Sosial Kabupaten Berau telah memanfaatkan anggaran belanja dengan baik dimana realisasi belanja yang telah dilakukan oleh Dinas Sosial Kabupaten Berau lebih kecil dari anggaran yang telah direncanakan. Dengan demikian 
dilihat dari analisis varians belanja Dinas Sosial Kabupaten Berau dapat dikatakan telah memanfaatkan APBD dengan baik.

\section{Analisis Pertumbuhan Belanja}

Tahun 2017 terjadi penurunan pertumbuhan belanja yang bersaldo negatif Rp2.788.407.071 atau sebesar $-22,20 \%$ dari total realisasi belanja Tahun 2016. Pada dasarnya Dinas Sosial Kabupaten Berau telah mengupayakan pemanfaatan belanja dalam Anggaran Pendapatan dan Belanja Daerah agar selalu mengalami pertumbuhan yang positif.

\section{Analisis Keserasian Belanja}

Dinas Sosial Kabupaten Berau dalam mengalokasikan belanjanya memiliki kecenderungan persentase yang cukup besar digunakan untuk belanja operasi dimana selama Tahun 2016 sampai dengan Tahun 2017 rata-rata belanja operasi mencapai 95,88\% dari keseluruhan belanja. Sedangkan untuk belanja modal selama Tahun 2016 sampai dengan Tahun 2017, Dinas Sosial Kabupaten Berau mengalokasi-kan rata-rata hanya $4,12 \%$. Tahun 2017 , belanja operasi tersebut dialokasikan pada belanja pegawai Rp4.362.997.796 atau 92,41\% dan belanja barang Rp4.924.417.073 atau 87,76\%.

Berdasarkan analisis keserasian belanja tersebut di atas, maka dapat disimpulkan bahwa Dinas Sosial Kabupaten Berau dalam anggaran maupun realisasi belanjanya lebih besar porsinya pada belanja operasi bagi pelaksanaan program-program/kegiatan sosial kemasyarakatan.

\section{Analisis Efisiensi Belanja}

Dalam LRA Dinas Sosial Kabupaten Bera dapat diketahui bahwa terdapat efisiensi penggunaan anggaran belanja. Tahun 2016, total realisasi belanja sebesar 84,40\% dari total anggaran belanja yang dianggarkan Dinas Sosial Kabupaten Berau. Tahun 2017, total realisasi belanja sebesar $90,21 \%$ dari total anggaran belanja yang dianggarkan Dinas Sosial Kabupaten Berau.

Selama kurun waktu Tahun 2016 sampai dengan Tahun 2017 Dinas Sosial Kabupaten Berau telah melakukan efisiensi belanja dengan baik. Hal ini dapat dilihat dari rasio efisiensi belanja mulai Tahun 2016 sampai Tahun 2017 kurang dari 100\% dimana rata-rata efisiensi belanja sebesar $87,30 \%$.

\section{PENUTUP}

\section{Simpulan}

Berdasarkan hasil analisis yang telah dilakukan dapat disimpulkan bahwa menolak hipotesis yang telah diajukan sebelumnya, karena kinerja belanja dalam Laporan Realisasi Anggaran (LRA) pada Dinas Sosial Kabupaten Berau menurun pada Tahun 2017, dibuktikan dari:

1. Tahun 2017 jumlah anggaran belanja (Rp10.830.810.200) dengan realisasi belanja (Rp9.770.219.869) menurun pada Tahun 2016, anggaran belanja Rp14.879.889.739 dan realisasinya $\mathrm{Rp} 12.558 .626 .940$.

2. Varians belanja pada Tahun 2017 (9,79\%) lebih rendah dari Tahun 2016 (15,60\%). Rasio pertumbuhan belanja pada Tahun 2017 turun sebesar 22,20\%.

\section{Saran}

1. Penyerapan anggaran belanja pada Dinas Sosial Kabupaten Berau Tahun 2017 sudah baik walaupun nilai anggaran yang diberikan lebih kecil dari Tahun 2016, maka disarankan kiranya dapat lebih mengoptimalkan lagi penyerapan dana anggaran 
tersebut agar tahun-tahun selanjutnya bisa mendapatkan apresiasi dari Pemerintah Daerah dengan memberikan nilai anggaran yang lebih tinggi.

2. Persentase alokasi realisasi belanja operasi sangat besar dibandingkan persentase untuk belanja modal yang hanya berada dibawah $5 \%$, untuk itu disarankan agar dapat dilakukan perimbangan antara belanja modal dan belanja operasi. Belanja modal dapat berupa peningkatan infra-struktur, sarana dan prasarana yang sangat dibutuhkan dalam menunjang program-program dan kegiatan sosial kemasyarakatan yang menjadi isu strategis Dinas Sosial Kabupaten Berau.

3. Rasio pertumbuhan belanja yang menurun di Tahun 2017 hendaknya menjadi perhatian Dinas Sosial Kabupaten Berau, terutama dalam penyusunan mata anggaran untuk tahun-tahun selanjutnya sehingga meningkatkan rasio pertumbuhan belanja Dinas Sosial Kabupaten Berau.

\section{DAFTAR PUSTAKA}

Al Makka, Harry. 2015. Analisis Kinerja Belanja Daerah dalam Laporan Realisasi Anggaran pada Dinas Pendapatan Pengelolaan Keuangan dan Aset Daerah di Kota Kotamobagu. Jurnal Berkala Ilmiah Efisiensi, Volume 15 No. 04 Tahun 2015.

Anonim. 2005. Peraturan Pemerintah No.24 Tahun 2005 Tentang Standar Akuntansi Pemerintahan. Bandung: Fokusmedia. . 2012. Peraturan Pemerintah No.71 Tahun 2010 tentang Standar Akuntansi Pemerintahan. Bandung: Fokusmedia. 2012. Al-Quran dan Terjemahnya. Jakarta: Departemen Agama RI. . 2013. Modul Belanja Daerah - Kursus Keuangan Daerah (KKD). Direktorat Jendral Perimbangan Keuangan Kementerian Keuangan RI, Jakarta.

Arif, Muchlis Bahtiar dan Iskandar. 2009. Akuntansi Pemerintahan. Jakarta: Akademia.

Bastian, Indra. 2010. Akuntansi Sektor Publik Suatu Pengantar, Edisi Ketiga. Jakarta: Erlangga.

Halim, Abdul dan Muhammad Syam Kusufi. 2013. Akuntansi Sektor Publik: Akuntansi Keuangan Daerah, Edisi 4. Jakarta: Salemba Empat.

Halim, Abdul, Yanuar E. Restianto dan I Wayan Karman. 2010. Sistem Akuntansi Sektor Publik. Yogyakarta: UPP STIM YKPN.

Harahap, Sofyan Syafri. 2013. Analisis Kritis Atas Laporan Keuangan, Cetakan Kesebelas. Jakarta: Penerbit Rajawali Pers.

Huda, Nurul dkk. 2012. Keuangan Publik Islam: Pendekatan Teoritis dan Sejarah. Jakarta: Kencana.

Kuncoro, Mudrajad. 2009. Metode Riset Untuk Bisnis dan Ekonomi. Edisi Ketiga. Jakarta: Erlangga.

Mahmudi. 2010. Analisis Laporan Keuangan Pemerintah Daerah. Yogyakarta: Unit Penerbit dan Percetakan STIM YKPN.

Mardiasmo. 2009. Akuntansi Sektor Publik. Yogyakarta: Andi Offset.

Mahsun, Muhamad. 2009. Pengukuran Kinerja Sektor Publik. Yogyakarta: BPFE.

Palilingan, Anastasia Friska. 2015. Analisis Kinerja Belanja Dalam Laporan Akuntabilitas Kinerja Instansi Pemerintahan pada Dinas Pendapatan Kota Manado. Jurnal EMBA, Vol.3 No.1 Maret 2015, Hal. 17-25, ISSN 2303-1174. 
Rodiansyah. 2017. Analisis Laporan Akuntabilitas Kinerja Instansi Pemerintah pada Dinas Pekerjaan Umum Kabupaten Berau. Skripsi. Sekolah Tinggi Ilmu Ekonomi Muhammadiyah Tanjung Redeb, Berau.

Rukayah. 2017. Analisis Laporan Realisasi Anggaran dengan Menggunakan Rasio Efektivitas dan Rasio Efisiensi pada Kantor Badan Perijinan Terpadu dan Penanaman Modal Kabupaten Serang. Jurnal Akuntansi. Vol 4 No. 2 Juli 2017, pISSN 2339-2436, e-ISSN 2549-5968. 